\title{
Asymmetrical Flow Simulation of Icing Effects in S-Duct Inlets at Angle of Attack
}

\author{
Wonjin Jin, ${ }^{1}$ Ray R. Taghavi ${ }^{2}$ and Saeed Farokhi ${ }^{2, *}$ \\ ${ }^{1}$ Korea Aerospace Research Institute, Daejeon, \\ South Korea \\ 2 The University of Kansas, Lawrence, USA
}

\begin{abstract}
The effect of flow angularity on an S-duct inlet with icing is computationally investigated. Flow angularity is simulated through angle-of-attack, and sideslip in addition to asymmetrical ice accretion on the inlet lip. A commercial CFD code, STAR-CCM+ is used for the steadystate computations with the shear-stress transport (SST) $k$ $\omega$ turbulence model. Symmetrical and asymmetrical glaze ice shapes are computationally simulated on the inlet lip. The symmetrical glaze ice uniformly covers the entire cowl lip; whereas the asymmetrical glaze ice is simulated on a $1 / 4$ sector of the inlet lip and is positioned on top, bottom or side of the inlet lip. The results indicate that flow angularity, whether in angle-of-attack or sideslip, aggravates the low performance of inlets with icing. The total pressure recovery suffers an additional $\sim 2 \%$ loss and the inlet mass flow rate drops by $\sim 7 \%$ when the inlet is at $+20^{\circ}$ angle of attack, as compared to zero angle, for flight Mach number of 0.34. The extent of loss in total pressure and a drop in mass flow rate depends on the asymmetrical icing location as well as the inlet angle-of-attack and sideslip. In addition, the ice-induced flow blockage is identified as a critical inlet performance parameter, since the symmetrical $\left(360^{\circ}\right)$ glaze ice with its wider flow blockage creates a lower total pressure recovery than the asymmetrical $\left(90^{\circ}\right)$ glaze ice at all angles of attack or sideslip.
\end{abstract}

Keywords. Icing, S-Duct, Engine Inlet Performance, Numerical Computation.

\author{
1 Nomenclature \\ Letters \& Symbols \\ A Area $\left(\mathrm{m}^{2}\right)$ \\ a Semi-major axis of ellipse (m) \\ b Semi-minor axis of ellipse (m) \\ D Diameter $(m)$ \\ L Length (m) \\ LWC Liquid water contents $\left(\mathrm{g} / \mathrm{m}^{3}\right)$ \\ MVD Mean volume diameter (mm) \\ M Mach number $(\sim)$ \\ $\mathrm{p} \quad$ Pressure $(\mathrm{kPa})$ \\ $\mathrm{R} \quad$ Radius (m) \\ $\mathrm{T} \quad$ Temperature $\left({ }^{\circ} \mathrm{C}\right)$ \\ $\mathrm{V} \quad$ Velocity $(\mathrm{m} / \mathrm{s})$ \\ $\mathrm{y}^{+} \quad$ Non-dimensional wall distance $(\sim)$ \\ $\mathrm{X}, \mathrm{Y}, \mathrm{Z}$ Cartesian coordinates $(\sim)$ \\ Greek Symbols \\ $\alpha \quad$ Inlet angle of attack (deg.) \\ $\beta \quad$ Inlet sideslip angle (deg.) \\ $\theta \quad$ Circumferential angle (deg.) \\ $\rho \quad$ Density $\left(\mathrm{g} / \mathrm{m}^{3}\right)$

\section{Subscripts} \\ cl Centerline \\ ef Engine face \\ o Original glaze \\ s Static \\ se Secondary flow \\ sh Sharp glaze \\ t Total \\ th Inlet throat \\ $\infty \quad$ Free-stream \\ Superscript \\ Area-averaged
}

\section{Introduction}

Ice accretes on the surfaces of the aircraft flying through clouds of super-cooled water droplets. Ice accretions not only on wings, but also on engine inlets and empennage seriously impact aircraft stability and control. A total of 803 aviation accidents and incidents from 1975 to 1988 were caused by in-flight icing problems ([1]). Therefore, detailed experimental and numerical studies have been carried out to
Corresponding author: Saeed Farokhi, Aerospace Engineering Department, The University of Kansas, Lawrence, KS 66045, USA; E-mail: sfarokhi@ku.edu.

Received: December 29, 2010. Accepted: February 20,2011. 
investigate the icing effects on the performance of airfoils and wings ([2-6]). However, less research is conducted on ice accretion on engine inlets, although the effects are hazardous to engines and aircraft. In particular, the ice accretion on the aircraft inlet lip can alter the shape of the cowl lip and may cause significant performance degradation of the engine inlet and compressor stall margin.

Acker et al. ([7]) first conducted a flight test to investigate the icing effects on a turbojet engine, and they found ice accretion on the engine inlet resulted in reduction of engine thrust ranging from 9 to 26 percent. Also, the combined loss of efficiency of the compressor and inlet diffuser were approximately of the same order of magnitude as the thrust loss. In addition, Gelder et al. ([8]) studied the total pressure distortion of a full-scale unheated supersonic nose inlet in the subsonic icing conditions. Their study showed that in the icing condition of $\mathrm{LWC}=1.3 \mathrm{~g} / \mathrm{m}^{3}$ with MVD $=16 \mathrm{~mm}$, and in the test condition of $\mathrm{M}_{\infty}=0.27$, total pressure distortion increased from about 6 percent in clear air to 12.5 percent after 2 minutes of icing time. Concurrently, the area-averaged total pressure recovery decreased from $\sim 98$ to 94.5 percent. Bidwell et al. ([9]) calculated the impingement efficiencies and ice shapes for an axisymmetric inlet by using the LEWICE3D ice accretion program ([10]). In their work, the shapes of a typical rime and glaze ice on the axisymmetrical inlet lip were numerically defined in the icing conditions; $\alpha=\beta=0^{\circ}, \mathrm{V}_{\infty}=$ $75 \mathrm{~m} / \mathrm{s}, \mathrm{LWC}=0.2 \mathrm{~g} / \mathrm{m}^{3}, \mathrm{~T}_{s \infty}=-29.9^{\circ} \mathrm{C}(243.3 \mathrm{~K})$, icing time $=30$ minutes and $\alpha=\beta=0^{\circ}, \mathrm{V}_{\infty}=75 \mathrm{~m} / \mathrm{s}$, LWC $=0.695 \mathrm{~g} / \mathrm{m}^{3}, \mathrm{~T}_{s \infty}=-9.3^{\circ} \mathrm{C}(263.9 \mathrm{~K})$, icing time $=30$ minutes for rime and glaze, respectively. Also, the effects of the Bidwell's rime and glaze ice shape on the performance of the M2129 diffusing S-duct inlet were computationally investigated by Jin and Taghavi ([11]). In their investigation, the (area-averaged) total pressure recovery of the M2129 inlet decreased by 3.2 percent at $\mathrm{M}_{\infty}=0.23$ when the glaze ice was simulated on the inlet lip in the case of zero angle of attack, while only 0.2 percent-reduction occurred with the rime ice shape. The glaze ice characterized by two ice horns induced a strong inlet lip separation and lower total pressure recovery. On the other hand, the effect of the rime ice with a more streamlined shape had a relatively minor effect on the inlet performance.

A diffusing S-duct inlet configuration is commonly used for the modern aircraft due to its advantages in the installation of a propulsion system. A simple S-shape duct induces a secondary flow pattern that causes flow separation at the first bend. Also, a diffusing S-duct has an additional burden of potential flow separation due to the streamwise adverse pressure gradient in the diffuser. These secondary flow pattern and flow separations contribute to the problem of engine face distortion, in particular, total pressure distortion. The level of total pressure distortion that an inlet creates at the engine face affects the stability of the compressor and engine performance. Also, when ice accretes on an inlet lip, the original flow quality, i.e., total pressure recovery and low distortion, in an S-duct inlet can be substantially deteriorated due to the altered shape of the inlet lip. For instance, a sharp inlet lip at the ice-free condition induced a higher total pressure loss at the engine face, as compared to a blunt (ellipse) inlet lip, due to lip separation ([12]).

Moreover, in practical flight conditions, aircraft maneuver creates angles of attack and sideslip on the fuselage, wings, and engine inlets. The flowfield characteristics in an S-duct inlet thus depend on the inflow direction during the steady flight with an angle of attack and during an aircraft maneuver. An experimental study by Guo and Seddon ([13]) used a rectangular S-duct inlet and showed that the total pressure recovery and mass flow rate in the duct were adversely affected by incidence angle. The reduction of total pressure recovery was due to a larger vortex (secondary flow) formation and flow separation at the duct bend at a relatively high angle of attack. In addition, we know that the extent of flow separation at the incidence angle depends on the inlet lip geometry and flow condition, such as the flight Mach number ([13]). Therefore, we expect that the angle of attack or sideslip, along with the change of inlet lip geometry due to ice accretion adversely affect the engine face distortion level and inlet performance.

In the present study, the effects of the circumferentially symmetrical and asymmetrical ice shapes on an S-duct inlet performance at inlet angles of attack or sideslip were investigated. The flight (freestream) Mach numbers of $\mathrm{M}_{\infty}=0.13$ and 0.34 were tested and the Reynolds numbers based on the throat diameter of the clean inlet were $\operatorname{Re}=1.74 \times 10^{6}$ to $4.05 \times 10^{6}$. The angles of attack of $\pm 10^{\circ}$ and $\pm 20^{\circ}$ were considered for the study with the $+20^{\circ}$ representing the most severe flow environment for the S-duct with a downward bend. The angle of sideslip was chosen to be $+10^{\circ}$ and $+20^{\circ}$ (instead of $\pm 10^{\circ}$ and $\pm 20^{\circ}$ ) due to duct plane of symmetry. Although in real flight conditions that involve angle of attack or sideslip in icing conditions, ice accretion is both asymmetrical and time dependent ([9]); we have modeled the asymmetry of ice accretion through $90^{\circ}$ sectors around the cowl lip, and our simulation assumes that the ice shape and size is time independent, i.e., constant.

\section{Numerical Methodology}

The M2129 S-duct inlet has circular-cross sections with a diffusing S-bend and two constant-area parts, as shown in Figure 1. The detailed geometry of the inlet, in particular the diffusing S-bend part, was based on a study of Willmer et al. ([14]) and Gibb et al. ([15]). The entrance and outlet of the inlet are defined by throat and engine face, respectively, as shown in Figure 1. The constant-area parts extend from the $S$-bend to the throat and engine face by $2 \mathrm{D}_{\text {th }}$ and $1 \mathrm{D}_{\mathrm{th}}$, respectively. In addition, the area ratio of the engine 


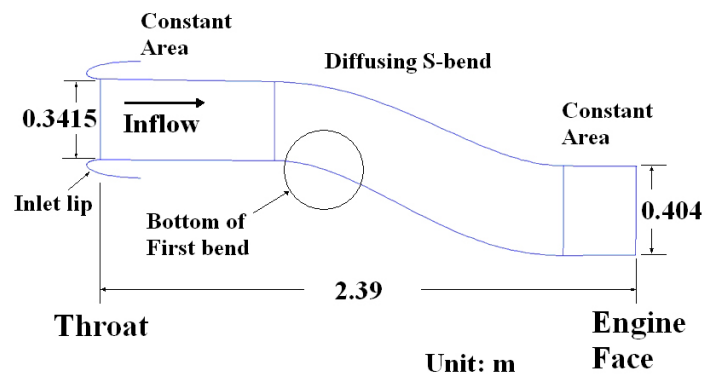

Figure 1. The M2129 S-duct inlet.

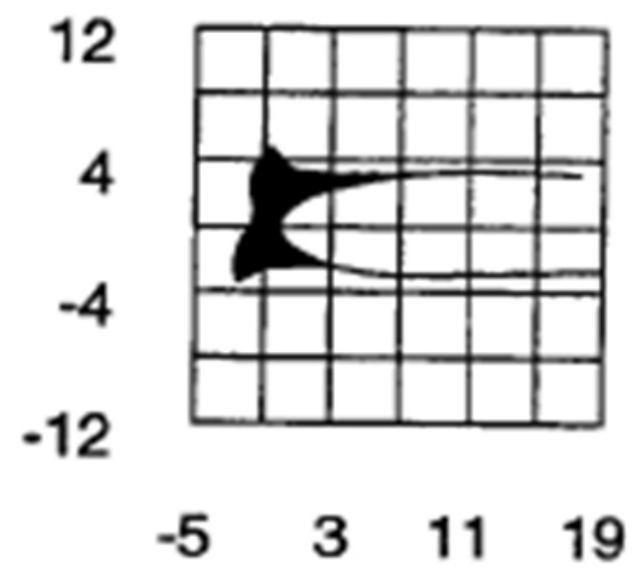

Figure 2. Numerical data for the glaze ice shape $\left(\alpha=\beta=0^{\circ}\right)([9])$.

face to throat is approximately 1.4 , and the total inlet length is about $7 \mathrm{D}_{\text {th }}$. The inlet size was set according to the diameter of an axisymmetric inlet from Papadakis et al. ([16]). The geometry and size of the inlet lip were also based on [16]. The shape of the inlet lip is elliptical and the ellipse ratio of the external and internal lips is $a / b=4.0$ and 2.5, respectively (as shown in Figure 1).

The glaze ice shape investigated in this study was based on the Bidwell's ([9]) 2-dimensional ice shape on an axisymmetric inlet lip which was numerically predicted by LEWICE3D code as shown in Figure 2. The icing conditions were: $\alpha=\beta=0^{\circ}, \mathrm{M}_{\infty}=0.23, \mathrm{~V}_{\infty}=75 \mathrm{~m} / \mathrm{s}$, $\mathrm{T}_{s \infty}=263.9 \mathrm{~K}, \mathrm{LWC}=0.695 \mathrm{~g} / \mathrm{m}^{3}, \mathrm{MVD}=20.36 \mathrm{~mm}$, and icing time $=30$ minutes ([9]). For the present study, the Bidwell's ice shape was slightly modified to define the sharp-glaze ice case where the thickness of the lower-glaze ice horn expected to affect the inlet flow was reduced to make a sharp horn (see Figure 3). In Figure 3, a circle was drawn to contact the maximum thickness portion of the lower-ice horn and the highlight of the inlet lip. Based

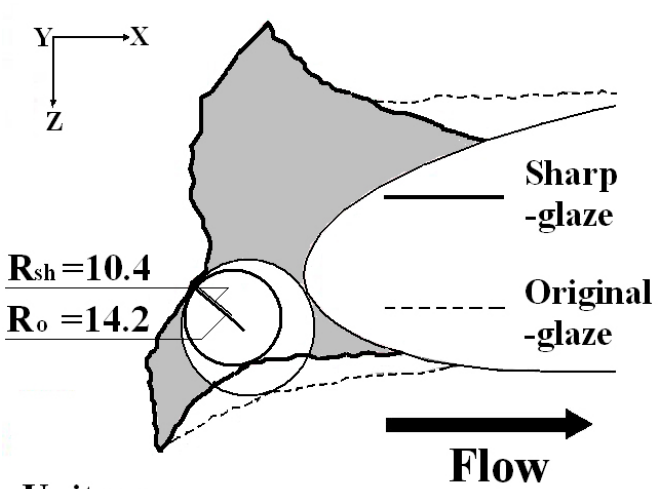

Unit: mm

Figure 3. Decrease in glaze ice horn thickness.

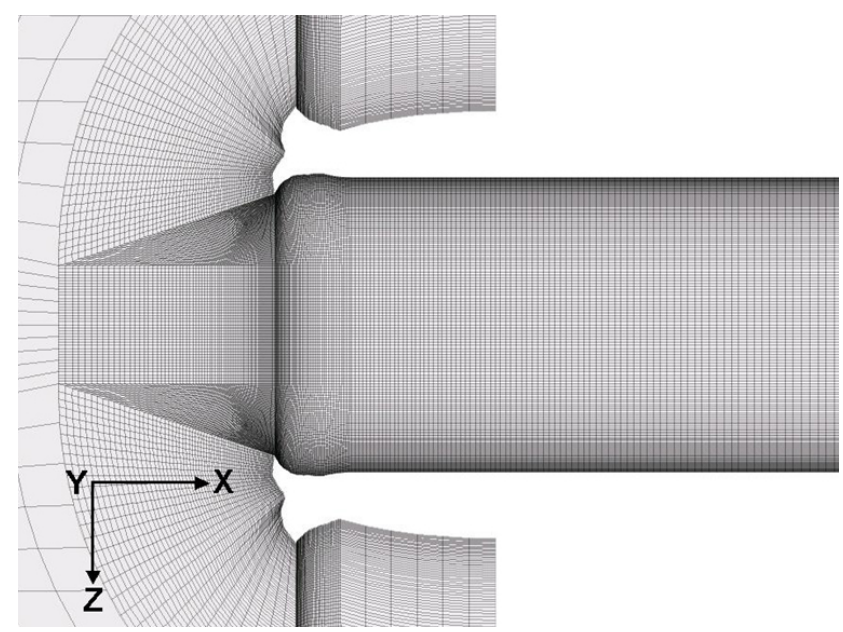

Figure 4. Mesh generation for the sharp-glaze ice.

on this circle, a smaller circle was drawn with 30 percent decrease in radius, and using the smaller circle the sharp-glaze ice geometry was defined. The radii of the original- and sharp-glaze ice horn were $\mathrm{R}_{\mathrm{o}}=14.2 \mathrm{~mm}$ and $\mathrm{R}_{\mathrm{sh}}=10.4 \mathrm{~mm}$, respectively. The sharp-glaze ice geometry serves as the most severe case in inlet icing research. Figure 4 shows the mesh generation around the sharp-glaze ice geometry on the inlet lip of the M2129 S-duct inlet using the GAMBIT 2.2.30 software ([17]). The roughness effect of the real glaze ice surface as not considered; as the observations focused on the effect of the ice geometry, in particular glaze ice horn on inlet performance. In addition, as shown in Figures 3 and 4, the rear part in the upper-glaze ice horn, which formed on the outside of the inlet lip and exerted no influence on the duct internal flow, was further simplified. Figure 5 shows the 3-dimensional modeling and mesh generations for the different glaze ice shapes. The symmetrical shape indicated the glaze ice accretion that occurred symmetrically on the inlet lip. However, for the asymmetrical shapes, the glaze ice was only simulated on a certain portion of the inlet lip with an exactly 

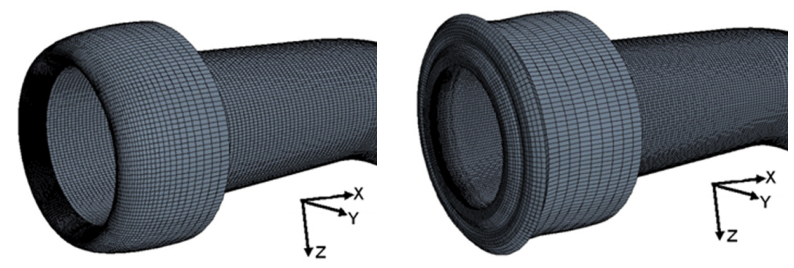

(b) Symmetrical glaze

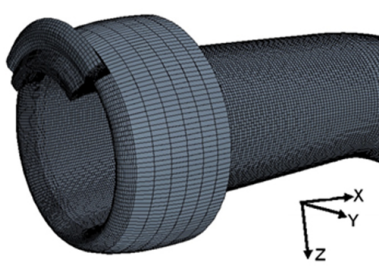

(c) Asymmetrical glaze - top $\left(\theta=315^{\circ}-45^{\circ}\right)$

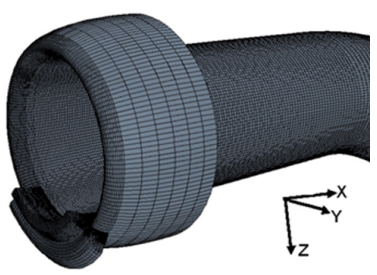

(d) Asymmetrical glaze bottom $\left(\theta=135^{\circ}-225^{\circ}\right)$

Figure 5. 3-dimensional modeling and mesh generation for the different glaze-iced inlet lips using GAMBIT.

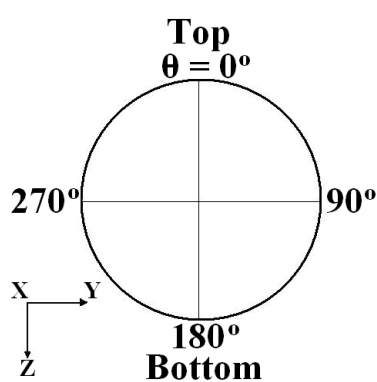

Figure 6. Definition of circumferential angle $(\theta)$.

$90^{\circ}$ extension in the circumferential direction. Since the $3-$ dimensional modeling of all glaze ice shapes was achieved by extending the 2-dimensional ice shape in the circumferential direction of the inlet lip, all ice shapes had the same side profile, which was the sharp-glaze ice. In addition, the asymmetrical shapes were categorized into top-, bottomand side-glaze ice, according to the locations of ice accretion: $\theta=315^{\circ}-45^{\circ}, 135^{\circ}-225^{\circ}$, and $45^{\circ}-135^{\circ}$, respectively, based on the definition of the circumferential angle $(\theta)$ shown in Figure 6. Both the symmetrical and asymmetrical ice shapes were assumed to simulate the ice accretion phenomena. The constant shape and size of ice accretion were assumed to hold for all angles of attack, sideslip angles, and freestream Mach numbers. Also note that the inlet frontal area was reduced by 21 percent with the simulated symmetrical glaze, whereas the asymmetrical case of $90^{\circ}$ azimuthal extent decreased the inlet area by a quarter, or $\sim 5 \%$.

All simulations and calculations were carried out by a commercial CFD code, STAR-CCM+ 2.10.013 ([18]), installed in the computing cluster at the Information and Telecommunication Technology Center (ITTC) at the University of Kansas. For the parallel computations, each simulation case was distributed among eight to twenty processors according to the mesh sizes. Each node has two Intel Xeon EM64T processors at $3.2 \mathrm{GHz}$ and 4,096 MB of RAM. The farfield (freestream) boundary condition was used for all the outer boundaries to simulate the freestream

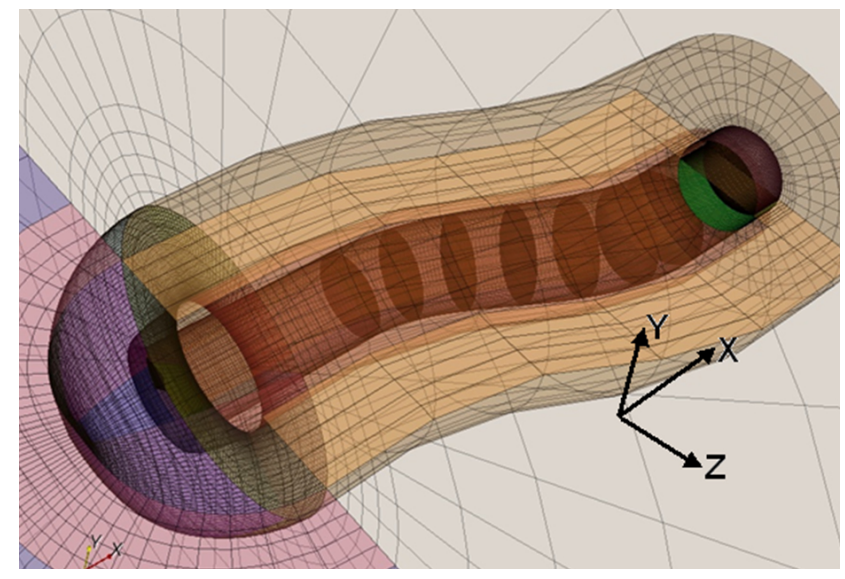

Figure 7. Mesh generations for outer and inner boundaries of M2129 S-duct inlet (clean inlet).

condition at infinity. The farfield boundaries that encompass the inlet lip region were radially extended by about the length of $20 \mathrm{D}_{\text {th }}$ into $\mathrm{x}-, \mathrm{y}-$, and $\mathrm{z}$-direction upstream to prevent the boundary effects on the simulation regions of interest. The inner and outer surfaces of the duct, and the cowl surface, including the iced lip region, were defined by the solid wall boundary condition, and no heat transfer was considered. In addition, several cross-sectional stations inside the duct, including the engine face, were used as control stations to assess the flow quality and inlet performance in icing conditions. 
Figure 7 shows the mesh generations for the outer and inner boundaries around the S-duct inlet. Using the GAMBIT software, the structured meshes for the iced inlet lip, S-duct with inner regions, and farfield boundary were generated for a total of 66 volumes. As shown in Figure 4, the mesh density around the glaze ice was increased in order to properly capture the anticipated flow separation from the ice horn. The number of mesh nodes in the duct section was $230 \times 160 \times 100$ in the axial, circumferential, and radial direction, respectively for the clean and icing cases. Therefore, the total numbers of mesh cells for all parts including the iced inlet lip and the farfield region were approximately 3.7, 5.2, and 5.5 million for the clean, symmetrical-glaze, and asymmetrical glaze cases, respectively. The mesh resolution in the near-wall region of turbulent boundary layers, represented by $\mathrm{y}^{+}$, is a critical issue in the computational simulations. In particular, a study on the mesh resolution showed that the accurate prediction of the flow separation and distortion in the M2129 S-duct inlet depended on the proper choice of $\mathrm{y}^{+}([19])$. Therefore, the all $y^{+}$wall treatment option in STAR-CCM+ was chosen to have reasonable results in the turbulent boundary layers at different freestream Mach numbers. By applying the wall treatment, the limitation of meshes with low and high $\mathrm{y}^{+}$can be improved, and a more realistic turbulent flow modeling can be achieved in the near wall region of the iced inlet lip and duct.

To properly simulate the subsonic-viscous flow in the M2129 inlet, multiple turbulence models were tested and compared to experimental measurements ([20]). It was concluded that the Shear Stress Transport (SST) $k-\omega$ model ([21]) showed the best performance for the baseline M2129 inlet, although the other turbulence models also produced relatively good results. The use of $k-\omega$ turbulence modeling in S-shape diffusers with vortex separation and compressible flow in transonic diffusers is also supported by other researchers $([22-24])$. The turbulence intensity and viscosity rate were set as $1 \%$ and 10 , respectively, for the freestream turbulence level. The coupled-implicit solver for the steady-state condition was utilized for the flow simulations, and the second-order upwind scheme was applied to spatial discretization. Since this simulation was carried out by the steady-state computation, time discretization error was not created. Also, the density change option using the ideal gas law was exercised in the computations since compressibility effects were expected due to flow acceleration inside the S-duct.

The freestream total pressure at sea level, $\mathrm{p}_{t \infty}=$ $101 \mathrm{kPa}$, was imposed on the farfield boundary condition. In addition, the static pressure and temperature of the farfield boundary condition were changed according to the flight Mach number. The freestream static pressure, $\mathrm{p}_{s \infty}$, ranged between $93.3 \mathrm{kPa}$ and $99.9 \mathrm{kPa}$ and static temperature, $\mathrm{T}_{s \infty}$, varied between $260.6 \mathrm{~K}$ to $265.7 \mathrm{~K}$ for $\mathrm{M}_{\infty}=$ 0.13 to 0.34 . The static temperature range corresponds to the glaze-icing condition $\left(\mathrm{T}_{s \infty}=263.9 \mathrm{~K}\right.$ at $\left.\mathrm{M}_{\infty}=0.23\right)$ according to Bidwell et al. ([9]). Other physical properties of air, such as viscosity and thermal conductivity, were also defined according to the icing condition in [9]. The simulations were run and monitored until the residuals for continuity equation, $\mathrm{x}, \mathrm{y}, \mathrm{z}$-velocity, energy equation, and turbulence factors dropped below $10^{-4}$ to $10^{-5}$ where the value of the area-averaged total pressure at the engine face changed by less than 0.5 percent between runs.

\section{Validation of Numerical Solution}

\subsection{Baseline M2129 S-Duct Inlet}

The numerical solutions of STAR-CCM+ for the baseline M2129 S-duct inlet were compared to experimental measurement data by AGARD Working Group 13 ([20]). The experimental analyses for the performance of only a baseline (clean) M2129 inlet were available; however, no validation data has been found for the icing cases. Also, the computational data for the baseline M2129 inlet using WINDUS code from [25] were provided for the comparison. For this validation, the size of the duct inlet was set based on the geometrical data from [20] and [25]. According to the modeling approach for the baseline M2129 inlet in [25], only half of the geometry was meshed due to the symmetry across the mid plane with the reflecting boundary condition, and the inlet lip and farfield region were not included. Consequently, the pressure-inlet and pressure-outlet boundary condition was applied, and the static pressure at the engine face was varied to obtain the throat Mach number range, $\mathrm{M}_{\mathrm{th}}=0.1$ to 0.77 . Also, angles of attack or sideslip angle were not considered $\left(\alpha=\beta=0^{\circ}\right)$. The main features of computational setup, including the mesh size and turbulent model, for STAR-CCM+ and WIND-US are listed in Table 1.

In Figure 8 the comparison of total pressure recoveries by STAR-CCM+, experiment, and WIND-US is plotted. The total pressure recovery, the area-averaged total pressure at the engine face normalized to the freestream total pressure $\left(\overline{\mathrm{p}}_{\mathrm{tef}} / \mathrm{p}_{t \infty}\right)$, measures the extent of the average irreversibility or loss in the inlet that is directly related to (average) inlet adiabatic efficiency. In an S-duct inlet, viscous flow separation at the first convex bend and subsequent turbulent mixing is the main source of total pressure loss. Also, as indicated in Figure 8, total pressure recovery decreases with increasing throat Mach number. The enlarged flow separation and turbulent mixing with higher Mach numbers in the duct create lower total pressure recovery and higher engine face distortion. The STAR-CCM+ results accurately predict the experimental measurements (as shown in Figure 8), with similar variation and level of total pressure recovery with increasing throat Mach number. In particular, a relatively good agreement is obtained 


\begin{tabular}{|c|c|c|c|c|c|c|c|}
\hline Code & Ice & Inlet lip & Mesh type & $\begin{array}{l}\text { Meshed } \\
\text { Part }\end{array}$ & $\begin{array}{l}\text { Mesh size } \\
\text { (Total cell } \\
\text { No.) }\end{array}$ & $\begin{array}{l}\text { Boundary } \\
\text { condition }\end{array}$ & $\begin{array}{l}\text { Turbulent } \\
\text { model }\end{array}$ \\
\hline $\begin{array}{l}\text { STAR- } \\
\text { CCM+ }\end{array}$ & \multirow{2}{*}{ No } & \multirow{2}{*}{$\begin{array}{l}\text { No } \\
\text { (baseline- } \\
\text { inlet) }\end{array}$} & Structured & \multirow{2}{*}{ Half Plane } & 180,000 & \multirow{2}{*}{$\begin{array}{l}\text { Pressure } \\
\text { inlet - } \\
\text { Pressure } \\
\text { outlet }\end{array}$} & SST $k-\omega$ \\
\hline $\begin{array}{l}\text { WIND-US } \\
\text { ([25]) }\end{array}$ & & & Unstructured & & 830,000 & & $\begin{array}{l}\text { Spalart- } \\
\text { Allmaras }\end{array}$ \\
\hline
\end{tabular}

Table 1. Computational setups for STAR-CCM+ and WIND-US ([25]).

\begin{tabular}{|c|c|c|c|c|c|c|c|}
\hline Case & & Code & Inlet lip & $\begin{array}{l}\text { Mesh } \\
\text { type }\end{array}$ & $\begin{array}{l}\text { Meshed } \\
\text { part }\end{array}$ & $\begin{array}{l}\text { Mesh nodal No. } \\
\text { (Duct only) }\end{array}$ & $\begin{array}{l}\text { Total cell No. (In- } \\
\text { cluding Far-field } \\
\text { region) }\end{array}$ \\
\hline \multirow{2}{*}{ Coarse } & Clean & \multirow{2}{*}{ FLUENT } & \multirow{4}{*}{$\begin{array}{l}\text { Yes } \\
\text { (Including } \\
\text { Farfield } \\
\text { region) }\end{array}$} & \multirow{4}{*}{ Structured } & \multirow{2}{*}{ Half plane } & \multirow{2}{*}{$\begin{array}{l}140 \times 40 \text { (half) } \\
\times 70 *\end{array}$} & 651,200 \\
\hline & Glaze & & & & & & 771,200 \\
\hline \multirow{2}{*}{ Fine } & Clean & \multirow{2}{*}{$\begin{array}{l}\text { STAR- } \\
\text { CCM+ }\end{array}$} & & & \multirow{2}{*}{ Whole } & \multirow{2}{*}{$\begin{array}{l}230 \times 160 \\
(\text { whole }) \times 100 *\end{array}$} & $3,722,300$ \\
\hline & Glaze & & & & & & $5,194,300$ \\
\hline
\end{tabular}

Table 2. Mesh generation for STAR-CCM+ and FLUENT $(*$ Streamwise $\times$ circumferential $\times$ radial direction).

by STAR-CCM+ near $\mathrm{M}_{\mathrm{th}}=0.8$, where the strong flow separation and mixing are expected. The STAR-CCM+ result predicts a mean total pressure recovery of 0.958 at $\mathrm{M}_{\mathrm{th}}=0.77$, whereas the experimental result is about 0.96 at $\mathrm{M}_{\mathrm{th}}=0.78$ ([20]). Also, compared to the WIND-US data, STAR-CCM+ produces a well-matched characteristic of mean total pressure recovery, although the mesh generation and turbulent modeling for both codes are different. As noted in Table 1, the structured mesh with the SST $k-\omega$ model and the unstructured mesh with the Spalart-Allmaras model were utilized in STAR-CCM+ and WIND-US code, respectively. In addition, the difference in mesh size for both codes ( 0.18 vs. 0.83 million) induces a minor effect on the simulations of the inlet performance. The mean total pressure recovery by WIND-US is 0.957 at $\mathrm{M}_{\mathrm{th}}=0.78$ ([25]).

\subsection{Iced M2129 S-Duct Inlet}

As noted earlier, there are no experimental data available for iced S-duct inlets. Therefore, the validity of STAR-CCM+ for the M2129 inlet was assessed through two mesh densities and another CFD code, FLUENT ([26]). Both the clean and symmetrical glaze cases were tested and the inlet lip and farfield region were also meshed in order to simulate the ice on the inlet lip. The inlet size and inlet-lip shape were set using the information available in Papadakis et al. ([16]), and no angle of attack or sideslip angle was applied $\left(\alpha=\beta=0^{\circ}\right)$. Based on the symmetrical-glaze cases, the total cell number of the coarse mesh was about 15 percent of that of the fine mesh, since the mesh covered only half

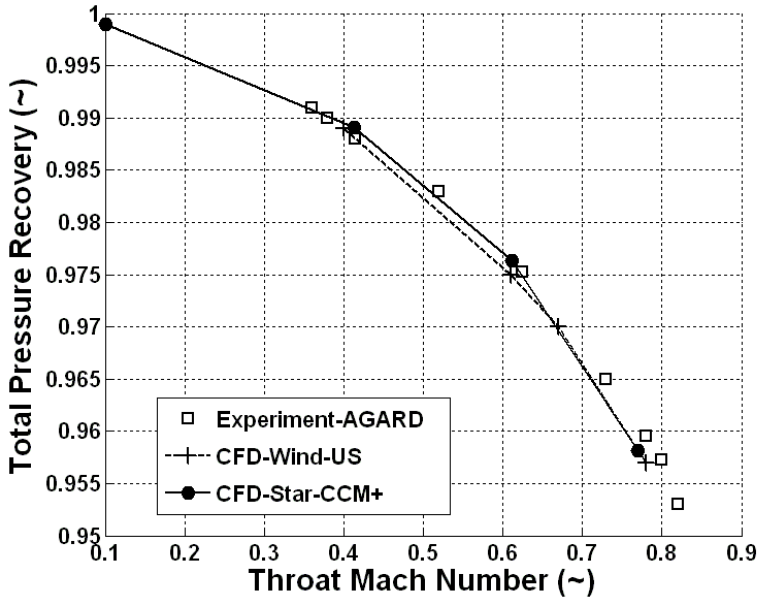

Figure 8. Total pressure recovery $\left(\overline{\mathrm{p}}_{\text {tef }} / \mathrm{p}_{t \infty}\right)$ in the baseline M2129 S-duct inlet $\left(\alpha=\beta=0^{\circ}\right)$.

the geometry according to the symmetry plane with reduced nodal number as shown in Table 2. The fine- and coarsemesh cases were solved by STAR-CCM+ and FLUENT, respectively, applying the same turbulence modeling, the SST $k-\omega$. Other computational parameters, such as boundary conditions and solver choice, were set up as presented in the "Numerical Methodology" section.

Figure 9 shows the effect of mesh density on total pressure recovery for the freestream Mach numbers, $\mathbf{M}_{\infty}=$ $0.13,0.25,0.34$, and 0.475 . These approximately correspond to the throat Mach numbers of $\mathrm{M}_{\mathrm{th}} \approx 0.2,0.4,0.6$, 
and 0.8 , respectively, measured in the clean inlet throat. As can be seen in the result, the total pressure recoveries from the two-mesh density levels are in a relatively good agreement at all Mach numbers, in particular for symmetricalglaze cases. The clean case shows more deviations, compared to the symmetrical-glaze cases; however, the maximum deviation that occurs at $\mathrm{M}_{\infty}=0.475$ is only about 0.8 percent $\left(\overline{\mathrm{p}}_{\text {tef }} / \mathrm{p}_{t \infty}=0.94\right.$ and 0.947 for the cleancoarse and clean-fine mesh, respectively). Also, the discrepancy caused by different computational dissipations between STAR-CCM+ and FLUENT seems to be insignificant.

The comparison of the inlet mass flow rates, calculated at the engine face $\left(\bar{\rho}_{\mathrm{ef}} \mathrm{A}_{\mathrm{ef}} \overline{\mathrm{V}}_{\mathrm{ef}}\right)$ is presented in Figure 10. Again, obtaining similar results at each freestream Mach number suggest that the effect of mesh density, as well as the code, on the inlet mass flow rate is relatively small. In particular, for the symmetrical-glaze case, the deviations of the coarse mesh at all Mach numbers are within 5 percent. Therefore, it can be concluded that STAR-CCM+ is still properly computing the performance of the M2129-S duct inlet under the icing effects, showing a relatively high-mesh independency. For the following simulations, however, the whole geometry, instead of the half geometry, was modeled for the clean and iced inlet cases due to the asymmetrical flow across the duct symmetry plane when the sideslip angles were applied. Also as noted in the "Numerical Methodology" section, fine mesh was used for all simulations, in spite of the need for more computational resources; approximately 3.7, 5.2, and 5.5 million cells were generated for the clean, symmetricalglaze, and asymmetrical glaze cases, respectively.

\section{Results and Discussion}

\subsection{Symmetrical Ice Shape}

Figure 11 gives the definition of the inlet angle of attack and inlet sideslip angle. In the present study, inlet angles of attack: $\alpha= \pm 10^{\circ}$ and $\pm 20^{\circ}$, and inlet sideslip angles: $\beta=+10^{\circ}$ and $+20^{\circ}$ were tested. Figure 12 shows the steady-state flowfield distributions of total pressure, static pressure and Mach number in the plane of symmetry of the M2129 S-duct inlet at the angles of attack or sideslip angle, when the symmetrical glaze ice accretes on the inlet lip. The freestream Mach number is $\mathrm{M}_{\infty}=0.34$ for all cases. In the clean inlet at $\alpha=0^{\circ}$ shown in Figure 12(a), the pressure gradient can be seen along with the flow deceleration and acceleration at the top $\left(\theta=0^{\circ}\right)$ and bottom $\left(\theta=180^{\circ}\right)$, respectively, of the first bend of the S-duct inlet. This typical flow pattern in a clean S-shaped inlet is the result of the imbalance between the centrifugal acceleration and radial pressure gradient at the first bend that induces 3-dimensional flow separation on the convex surface and shows as swirl or the secondary flow pattern at the engine

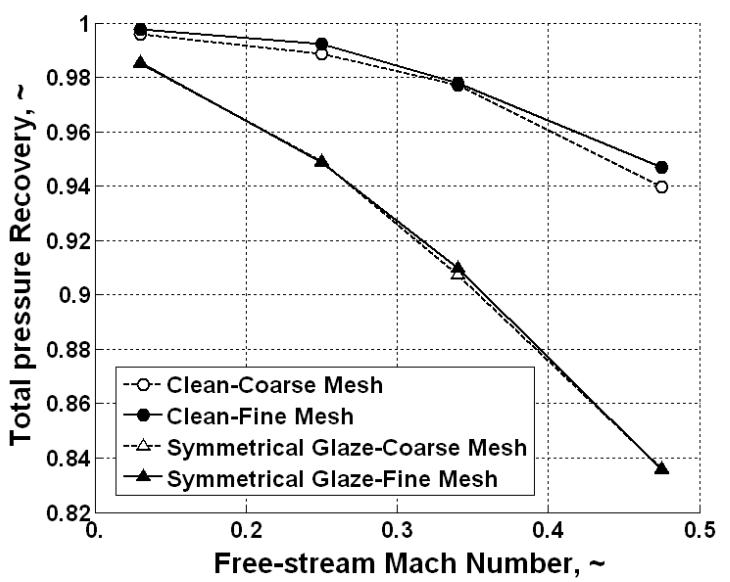

Figure 9. Total pressure recovery $\left(\overline{\mathrm{p}}_{\text {tef }} / \mathrm{p}_{t \infty}\right)$ by two mesh density levels $\left(\alpha=\beta=0^{\circ}\right)$.

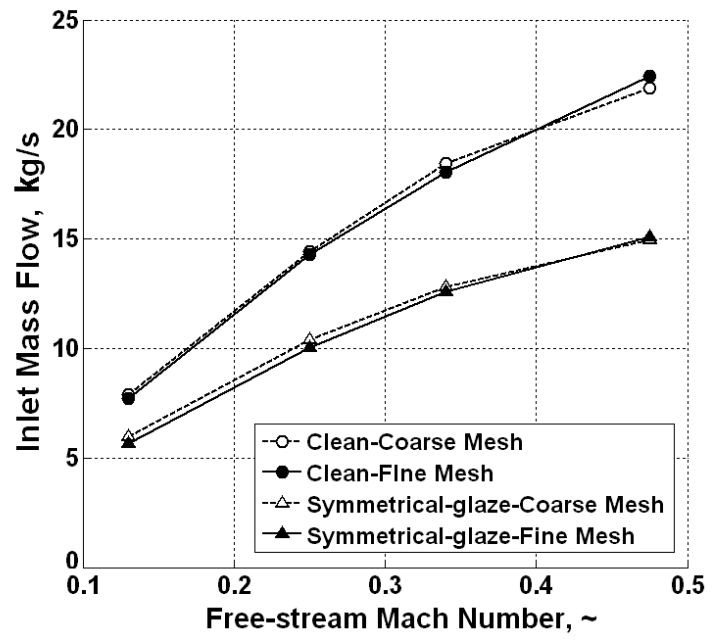

Figure 10. Inlet mass flow by two mesh density levels $\left(\alpha=\beta=0^{\circ}\right)$.

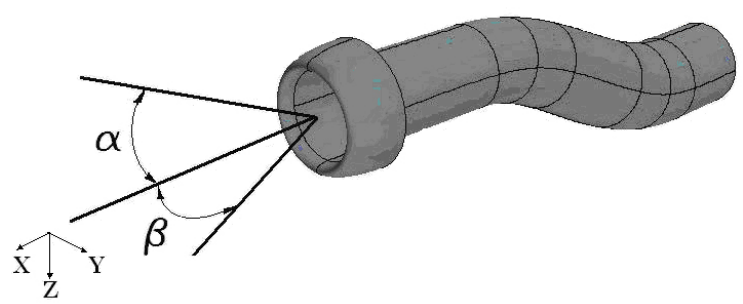

Figure 11. Definition of inlet angle of attack $(\alpha)$ and inlet sideslip angle $(\beta)$. 

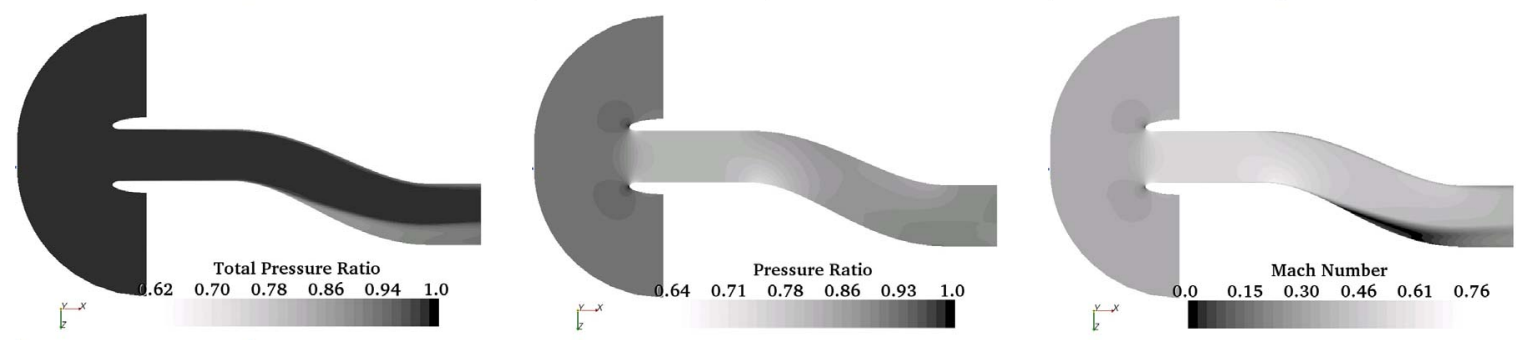

(a) Clean $\left(\alpha=0^{\circ}\right)$
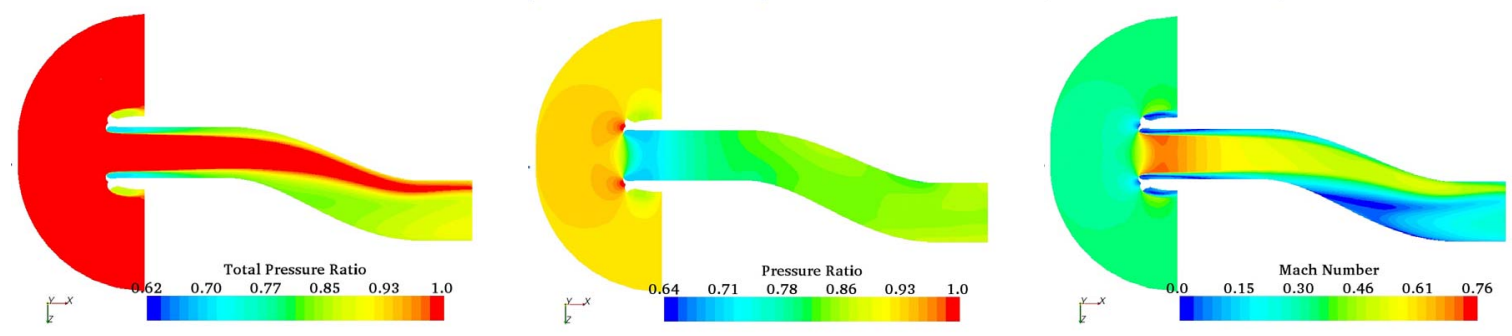

(b) Symmetrical glaze $\left(\alpha=0^{\circ}\right)$
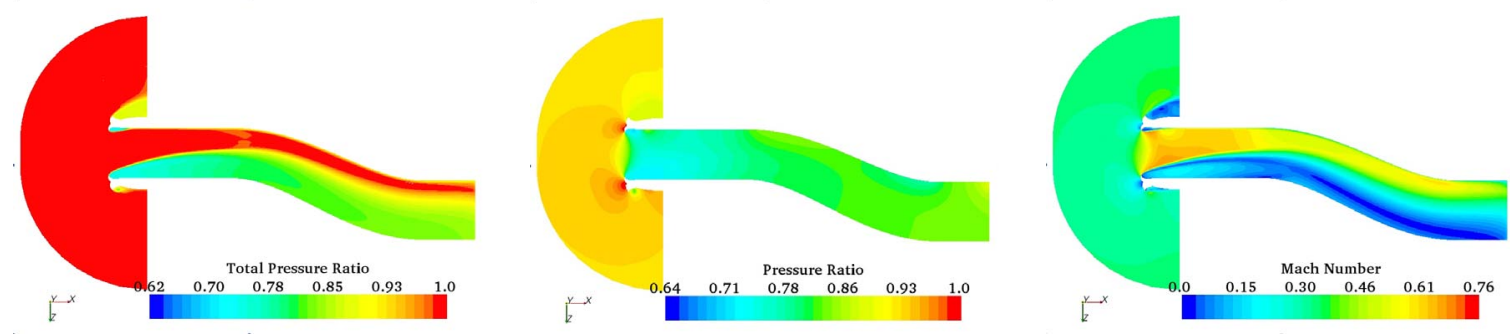

(c) Symmetrical glaze $\left(\alpha=+20^{\circ}\right)$
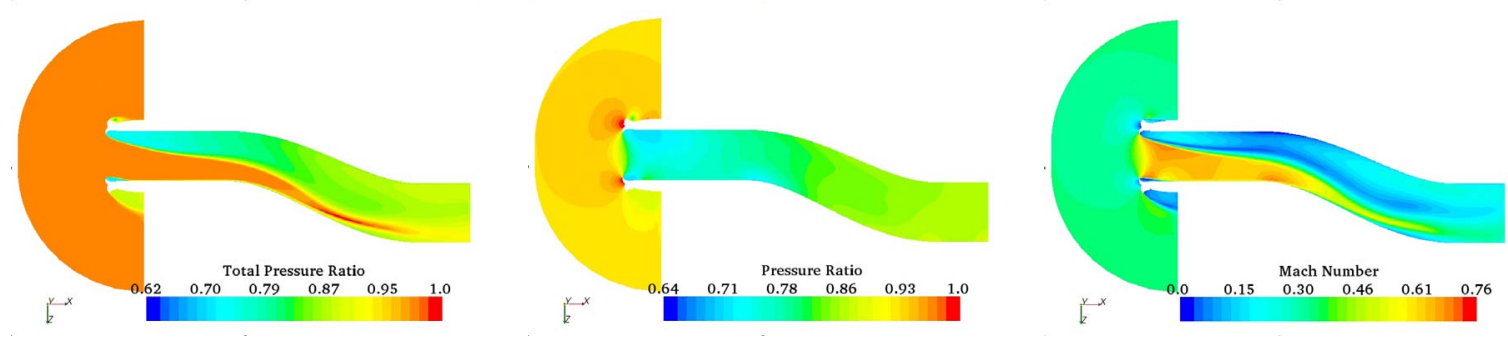

(d) Symmetrical glaze $\left(\alpha=-20^{\circ}\right)$
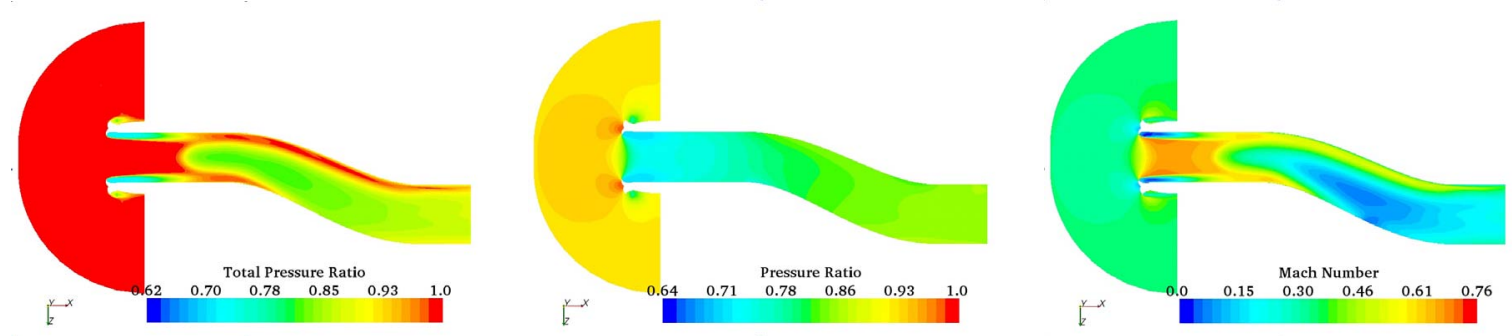

(e) Symmetrical glaze $\left(\beta=+20^{\circ}\right)$

Figure 12. Flowfield distributions of total pressure, static pressure and Mach number in the duct symmetry plane at angles of attack or sideslip $\left(\mathrm{p}_{t \infty}=101.1 \mathrm{kPa}, \mathrm{M}_{\infty}=0.34\right)$. First column: Total pressure $\left(\mathrm{p}_{t} / \mathrm{p}_{t \infty}\right)$. Second column: Static pressure $\left(\mathrm{p}_{s} / \mathrm{p}_{t \infty}\right)$. Third column: Mach number. 
face ([27]). However in the case of inlet with glazed ice, the initial flow separation occurs from the glaze ice horn, and the extent and size of the 3- dimensional flow separation at the first bend is increased as seen in the glaze ice case at $\alpha=0^{\circ}$ in Figure 12(b). An adverse (static) pressure gradient over the glaze ice horn causes the duct internal flow to separate and thus the flow separation at the first bend of the S-duct is enlarged. As expected, the case of $\alpha=+20^{\circ}$ poses the most severe adverse pressure gradient and flow separation through the first convex bend in the S-duct as shown in Figure 12(c), where massive 3-D separation appears on the bottom side, i.e., $\theta=180^{\circ}$. Consequently, a strong flow asymmetry and secondary flow pattern emerge at the engine face. When the angle of attack is changed to $\alpha=-20^{\circ}$, the role of the lower and upper cowl lip is reversed. Here, the flow separates from the upper $\operatorname{lip}\left(\theta=0^{\circ}\right)$ of the symmetrical ice as indicated in Figure 12(d). Due to flow separation from the upper lip, the core flow is swept to the bottom of the duct, and eventually disappears near the engine face where intense turbulent mixing creates a highly distorted flow at the engine face. A comparison between the angles of attack of $+20^{\circ}$ and $-20^{\circ}$ reveals a slightly lower total pressure loss in the latter case as compared to the former. The geometry of the S-bend that involves a downward shift of the entrance flow to the engine face is responsible for higher total pressure loss in $\alpha=+20^{\circ}$ as compared to $\alpha=-20^{\circ}$ inflow angularity. The manifestation of higher total pressure loss may be observed in larger flow separation zone, as shown in Figures 12(c) and 12(d). Figure 12(e) shows the flowfield in the duct plane of symmetry, with sideslip flow angle of $\beta=+20^{\circ}$. This severe flow angularity in sideslip exposes the inlet side $\left(\theta=270^{\circ}\right)$ with glaze ice to adverse pressure gradient and flow separation. Subsequent flow development in the duct exhibits 3dimensional mixing and flow distortion at the engine face, similar to angle-of-attack cases.

The total pressure patterns at the engine face, as well as the secondary flow fields, of the symmetrical glaze cases at the angles of attack or sideslip angles are compared in Figure 13. The secondary flow that induces the flow separation at the first bend of the clean S-duct inlet is further amplified, azimuthally rotates through the second bend, and affects the flow quality at the engine face in terms of inlet distortion. The typical secondary flow pattern of the clean cases shown in Figure 13, characterized by a double rotation about the duct symmetry plane, is from the effect of the first bend. In the clean cases, no significant change is observed in the level of total pressure losses, as well as the size of the counter-rotating vortices, under the effect of the angles of attack or sideslip angles. This is contrary to an experimental result which showed a larger vortex pair at the engine face at high incidence angle ([28]). The experiment showed that, in an S-duct inlet, the counter-rotating vortex pair became larger, due to the effect of an inlet lip flow separation at high incidence angles. However, only the S-bend part of the inlet was considered in the experimental study ([28]), while the constant-area part is added to the upstream of the S-bend section of the M 2129 inlet in the present study. The performance of the S-duct inlet without the constant-area part was sensitive to the inlet lip flow separation at high incidence angles. On the other hand, in the present study, the strength of the inlet lip flow separation at the high angle of attack is somewhat attenuated by the existence of the forward duct extension. However, the flow pattern outside the region of the counter-rotating vortex pair is slightly changed with varying the angle of attack or sideslip.

Unlike the clean cases, the symmetrical glaze induces a notable change in the total pressure pattern and the secondary flowfield at the engine face with the angles of attack or sideslip angles, as shown in Figure 13. Comparing the symmetrical glaze cases in Figure 13(a) and (b), it is clear that the secondary flow pattern at $\alpha=0^{\circ}$ is considerably affected by the positive angle of attack; the region of the large-swirling flow disappears at $\alpha=+20^{\circ}$. Also at $\alpha=+20^{\circ}$, a more substantial total pressure loss takes place at the bottom side of the engine face due to combined effect of the flow separations, i.e., the flow separation from the bottom portion of the symmetrical glaze ice at the positive angle of attack, and the stronger flow separation at the bottom of the first duct bend, which is a typical separation in an S-duct.

Figure 13(c) shows a change in flow pattern at negative angle of attack. At $\alpha=-20^{\circ}$, the flow separation from the top portion of the symmetrical ice induces a large total pressure loss at the top side of the engine face. Also, the core flow region almost completely disappears at the engine face at $\alpha=-20^{\circ}$, indicating a serious total pressure loss at the high negative angle of attack.

The sideslip case is shown in Figure 13(d). From this figure, we note a right-left asymmetry in the engine face distortion pattern at the positive sideslip angle. This unique distortion pattern is the result of the flow separation from the right side (as seen from behind the engine face) of the symmetrical ice at the positive sideslip angle, and the flow separation at the bottom of the first duct bend. The core flow region also completely disappears with the sideslip angle of $\beta=+20^{\circ}$.

The effect of angles of attack or sideslip as manifested in lower total pressure recovery $\left(\overline{\mathrm{p}}_{\text {tef }} / \mathrm{p}_{t \infty}\right)$ and mass flow rates $\left(\bar{\rho}_{\mathrm{ef}} \mathrm{A}_{\mathrm{ef}} \overline{\mathrm{V}}_{\mathrm{ef}}\right)$ as compared to the clean case is shown in Figure 14 and 15 respectively. The inlet mass flow rate in this study is the index of the air-swallowing capacity of an inlet. These figures show that all angles of attack or sideslip angles contribute to the degradation of the performance of the M 2129 S-duct inlet, combined with the icing effect in all freestream Mach numbers. The levels of total pressure recovery, as well as the inlet mass flow, decrease with most of the angles of attack or sideslip angles, and the decreases become more substantial as the angle or the freestream Mach number increases. At $\mathrm{M}_{\infty}=0.34$ we note that all the $20^{\circ}$ 

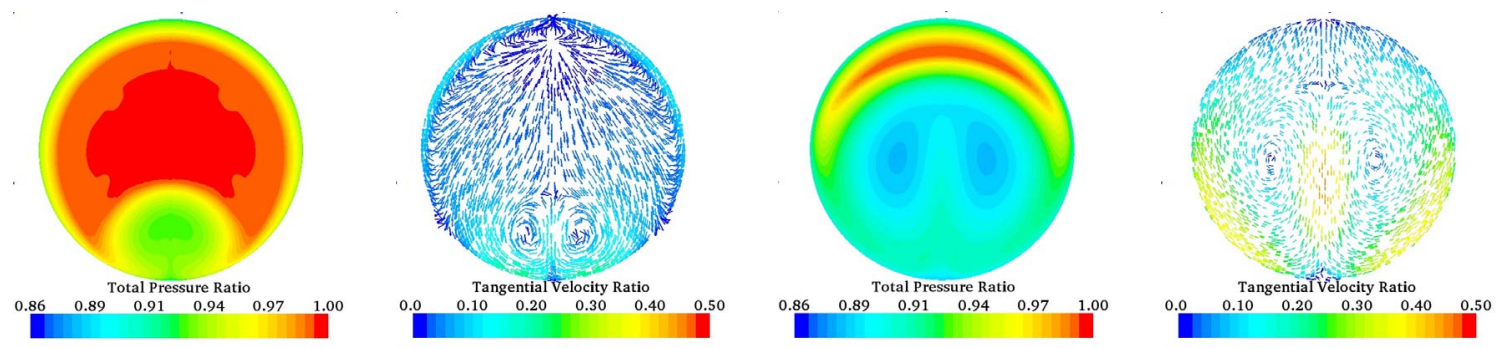

(a) $\alpha=0^{\circ}$
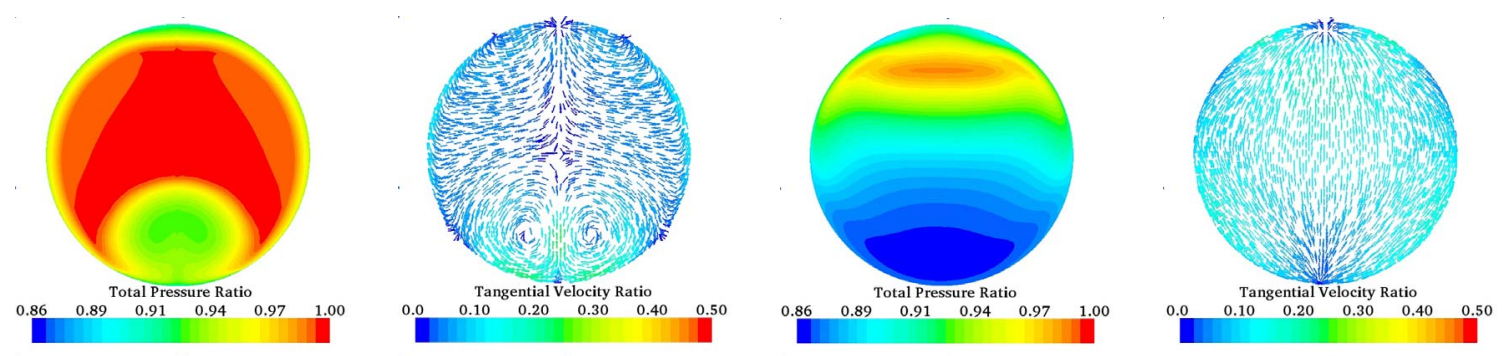

(b) $\alpha=+20^{\circ}$
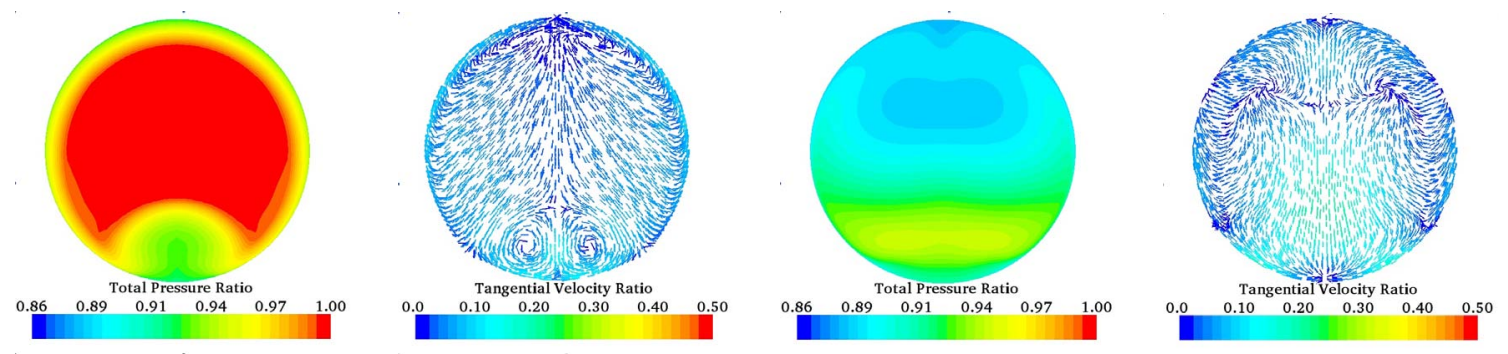

(c) $\alpha=-20^{\circ}$
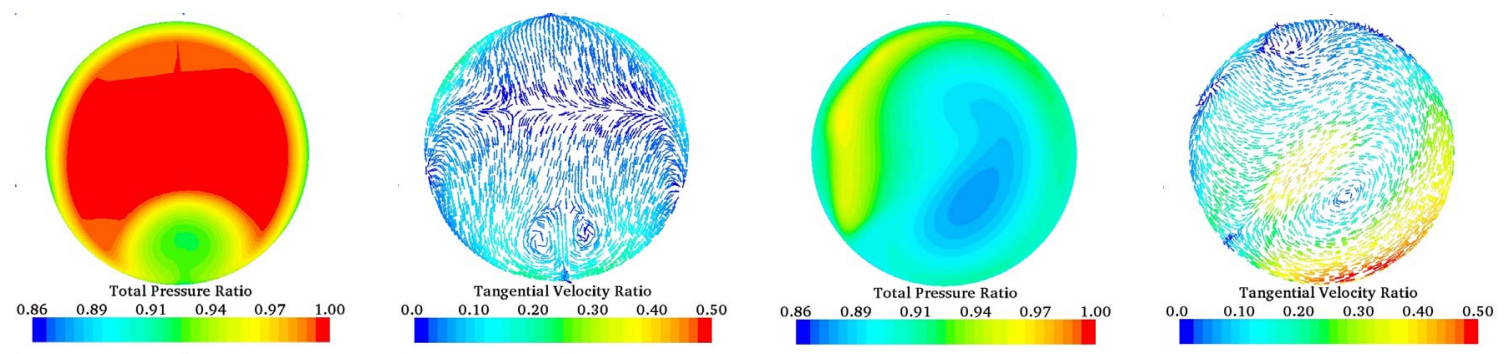

(d) $\beta=+20^{\circ}$

Figure 13. Total pressure $\left(\mathrm{p}_{t} / \mathrm{p}_{t \infty}\right)$ contours and the secondary flow fields $\left(\mathrm{V}_{\mathrm{se}} / \mathrm{V}_{\infty}\right)$ at the engine face at angles of attack or sideslip angle (clean vs. symmetrical glaze, $\mathrm{p}_{t \infty}=101.1 \mathrm{kPa}, \mathrm{M}_{\infty}=0.34$ ).

First column: Clean. Second column: Symmetrical glaze. 


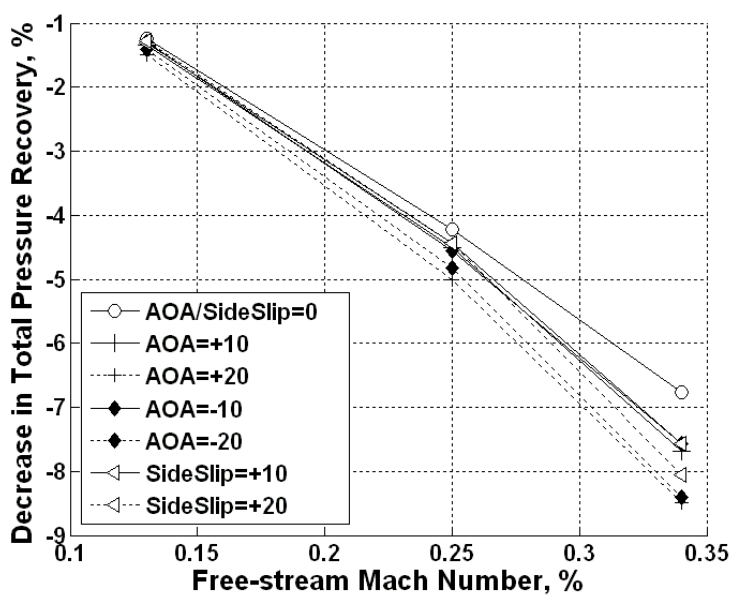

Figure 14. Decrement in total pressure recovery $\left(\overline{\mathrm{p}}_{\text {tef }} / \mathrm{p}_{t \infty}\right)$ at different angles of attack or sideslip angles (symmetrical glaze, $\mathrm{p}_{t \infty}=101.1 \mathrm{kPa}$ ) as compared to clean inlet.

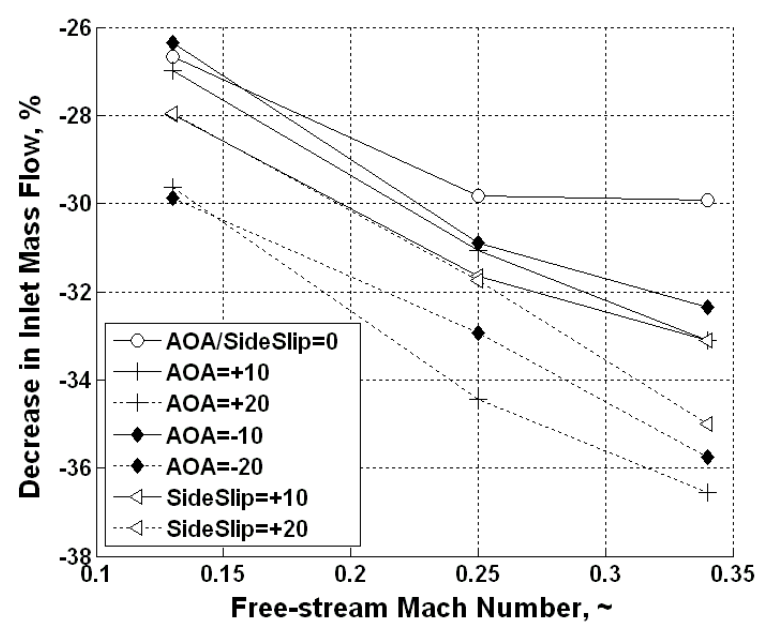

Figure 15. Decreases in inlet mass flow at different angles of attack or sideslip angles (symmetrical glaze).

cases induce larger losses and mass flow reductions as compared to the $10^{\circ}$ cases. Also, the greater decrease occurs at the positive angle of attack than at the negative angle of attack, and further decrease takes place at the negative angle of attack than at sideslip angle at $\mathrm{M}_{\infty}=0.34$ for $20^{\circ}$ cases. Therefore, the higher positive angle of attack, $\alpha=+20^{\circ}$, poses the most severe flow angularity case for a glaze ice inlet with an S-duct configuration, as noted earlier. Compared to the clean cases, the decreases in the total pressure recovery are approximately 6.8 and 8.5 percents at $\alpha=0^{\circ}$ and $+20^{\circ}$, respectively, with the symmetrical glaze ice at $\mathrm{M}_{\infty}=0.34$.

\subsection{Asymmetrical Ice Shapes}

The effect of the asymmetrical glaze ice shape at different inlet angles of attack and sideslip was also investigated. The asymmetry was created by placing $90^{\circ}$ sectors of glaze ice on the top, bottom or side of the inlet lip, as shown in Figures 5(b), (c), and (d), respectively. In this study, the inlet angles of attack of $\alpha= \pm 10^{\circ}$ and $\pm 20^{\circ}$, and inlet sideslip angles of $\beta= \pm 10^{\circ}$ and $\pm 20^{\circ}$ were examined. With the top-glaze ice accretion, the total pressure distortion pattern and the secondary flowfields at the engine face with respect to the angle of attack are presented in Figure 16. Again, the freestream Mach number is $\mathrm{M}_{\infty}=0.34$ for all cases. Another region of total pressure loss at the outer-top side of the engine face, due to the effect of the top glaze, becomes smaller with the positive angle of attack whereas it becomes larger with the negative angle of attack, as expected. Furthermore, the total pressure loss at the lower half of the engine face, which is caused by a typical flow separation from the duct bend, is also sensitive to the inflow angularity. However, it is clear from these distortion contours that higher levels of total pressure loss occurs with the negative angle of attack since the $90^{\circ}$ glaze ice sector is placed at the top.

Now, the bottom-glaze ice cases are presented in Figure 17. The region of total pressure loss at the bottom side of the engine face is induced by the effect of the downward duct bend plus the effect of the bottom-glaze ice accretion. In addition, the size of the separation region is enlarged when combined with the effect of the positive angle of attack. However, the formation of the counter-rotating vortex pair, which is originated from the duct bend, is gradually weakened with the positive angle of attack as seen in Figure 17(b). The negative angle of attack also affects the distortion pattern at the engine face. The case of $\alpha=-20^{\circ}$ in Figure 17(c) suggests that the region size of total pressure loss is significantly reduced, even compared to that of $\alpha=0^{\circ}$ case in Figure 17(a), showing another counterrotating vortex pair at the top side of the engine face. However, the vortex pair does not induce a serious flow separation at the top side as shown in the total pressure plot in Figure 17(c). Therefore, it is concluded that the positive angle of attack causes higher levels of total pressure loss when the bottom-glaze ice is simulated on the inlet lower lip.

The effect of the sideslip angles on the side-glaze ice accretion is also investigated as shown in Figure 18. The side ice accretion on the $90^{\circ}$-sector, $\theta=45^{\circ}-135^{\circ}$, was only considered since the other side-glaze portion of $\theta=225^{\circ}-$ $315^{\circ}$ was exactly symmetrical with respect to the duct plane of symmetry, as shown in Figure 5(d). The unique distortion patterns, which are biased to the left side of the engine face, are the result of the side-glaze ice. Also, the distortion patterns vary as the sideslip angle changes, producing different levels of swirl as seen in the secondary flow plots. However, the distorted region is larger with the more severe total 


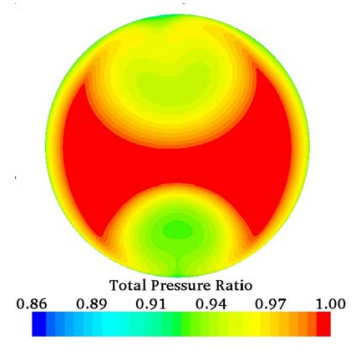

(a) $\alpha=0^{\circ}$

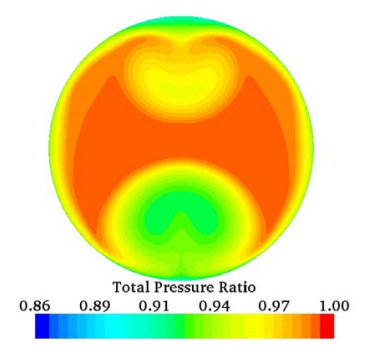

(b) $\alpha=+20^{\circ}$

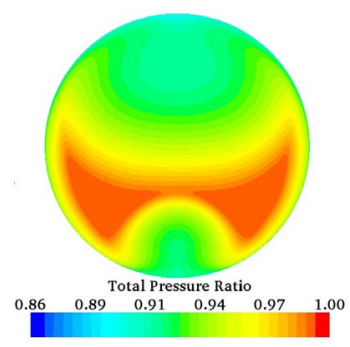

(c) $\alpha=-20^{\circ}$

Figure 16. Total pressure $\left(\mathrm{p}_{t} / \mathrm{p}_{t \infty}\right)$ contours and the secondary flow fields $\left(\mathrm{V}_{\mathrm{se}} / \mathrm{V}_{\infty}\right)$ at the engine face at angles of attack (asymmetrical glaze-top, $\mathrm{p}_{t \infty}=101.1 \mathrm{kPa}$, $\left.\mathrm{M}_{\infty}=0.34\right)$.

pressure loss at the negative sideslip angle $\left(\beta=-20^{\circ}\right)$, as compared to the case of the positive sideslip angle.

The quantified results presented by (area-averaged) total pressure recovery and inlet mass flow rate with angle of attack or the sideslip are summarized in Table 3. The flow losses in total pressure and mass flow rate are compared to clean S-duct inlet performance at each angle of attack or sideslip. Again, the freestream Mach number is $\mathrm{M}_{\infty}=0.34$ for all cases. Comparing the result of the symmetrical glaze case in Table 3(a) to those of the asymmetrical cases (of $90^{\circ}$ sectors) shown in Table 3(b) to (d), it is clear that the losses in total pressure recovery and inlet mass flow rate with symmetrical glaze ice are more substantial at all angles. As indicated in Table 3(a) and (b), the level of total pressure recovery further drops by $\sim 8 \%$ in symmetrical glaze condition as compared to the top-glaze cases, i.e., $\overline{\mathrm{p}}_{\text {tef }} / \mathrm{p}_{t \infty}=0.8979$ and 0.9722 for the symmetricaland top-glaze cases, respectively, at $\alpha=+20^{\circ}$. The wider
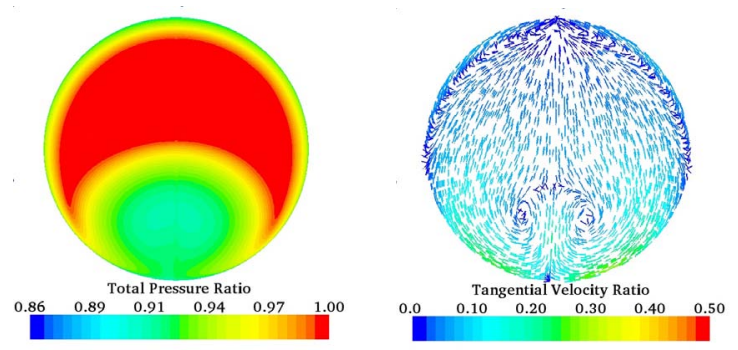

(a) $\alpha=0^{\circ}$
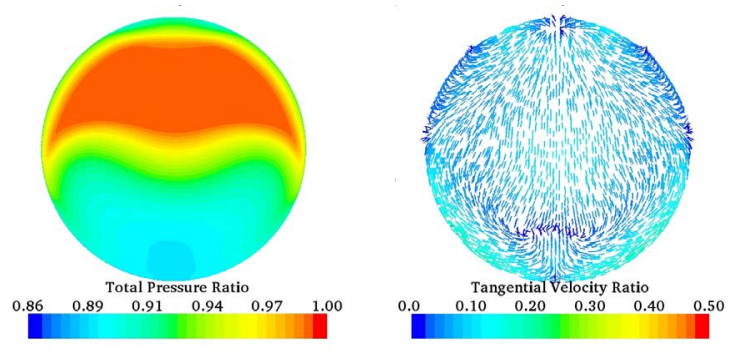

(b) $\alpha=+20^{\circ}$
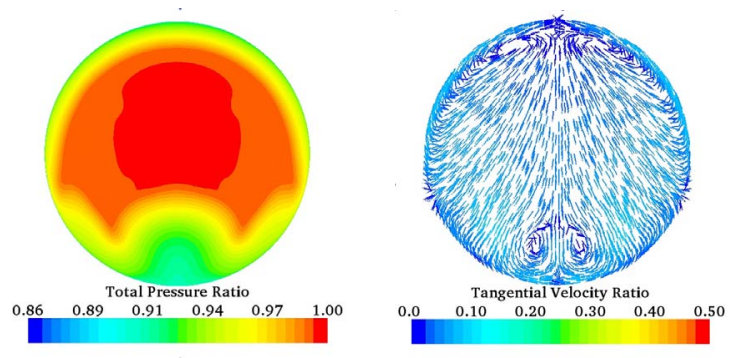

(c) $\alpha=-20^{\circ}$

Figure 17. Total pressure $\left(\mathrm{p}_{t} / \mathrm{p}_{t \infty}\right)$ contours and the secondary flowfields $\left(\mathrm{V}_{\mathrm{se}} / \mathrm{V}_{\infty}\right)$ at the engine face with angles of attack (asymmetrical glaze-bottom, $\mathrm{p}_{t \infty}=101.1 \mathrm{kPa}$, $\left.\mathrm{M}_{\infty}=0.34\right)$.

flow-blockage caused by the symmetrical ice accretion (as compared to a $90^{\circ}$-sector inlet lip icing) is deemed responsible for the higher levels of total pressure loss and a reduction in inlet mass flow rate. As we have noted earlier, the inlet frontal area was decreased by 21 percent with the simulated symmetrical glaze, and decreased by only 5 percent with the asymmetrical icing condition at the lip. Also, flow separation from the ice horn, which is the source of degradation in inlet performance, is more extensive when the symmetrical ice accretes on the inlet lip.

For the top-glaze ice cases in Table 3(b), the negative angles of attack produce more reduction in both the total pressure recovery and inlet mass flow, and the reduction is enhanced with increasing negative angle of attack. At $\alpha=-20^{\circ}$, the total pressure recovery and inlet mass flow drop about 3.5 and 15 percent, respectively, from the corresponding clean cases. In contrast, the positive angles of attack have a relatively minor influence on the inlet perfor- 
(a) Symmetrical glaze

\begin{tabular}{lllll}
\hline $\begin{array}{l}\text { Angle of at- } \\
\text { tack or sideslip } \\
\text { angle, deg. }\end{array}$ & $\begin{array}{l}\text { Total pressure } \\
\text { recovery, } \sim\end{array}$ & Decrease, $\%$ & $\begin{array}{l}\text { Mass flow rate, } \\
\mathrm{kg} / \mathrm{s}\end{array}$ & Decrease, $\%$ \\
\hline$\alpha=0$ & 0.9116 & -6.76 & 12.634 & -29.9 \\
\hline$\alpha=+10$ & 0.9057 & -7.69 & 12.4059 & -33.1 \\
\hline$\alpha=+20$ & 0.8979 & -8.49 & 11.8419 & -36.6 \\
\hline$\alpha=-10$ & 0.9098 & -7.57 & 12.5545 & -32.3 \\
\hline$\alpha=-20$ & 0.9011 & -8.42 & 11.928 & -35.7 \\
\hline$\beta=+10$ & 0.9091 & -7.57 & 12.5064 & -33.1 \\
\hline$\beta=+20$ & 0.9038 & -8.07 & 12.1910 & -35.0 \\
\hline
\end{tabular}

(b) Asymmetrical

\begin{tabular}{lllll}
\hline $\begin{array}{l}\text { Angle of at- } \\
\text { tack, deg. }\end{array}$ & $\begin{array}{l}\text { Total pressure } \\
\text { recovery, } \sim\end{array}$ & Decrease, $\%$ & $\begin{array}{l}\text { Mass flow rate, } \\
\mathrm{kg} / \mathrm{s}\end{array}$ & Decrease, \% \\
\hline$\alpha=0$ & 0.9731 & -0.47 & 17.7968 & -1.3 \\
\hline$\alpha=+10$ & 0.9719 & -0.95 & 17.8518 & -3.8 \\
\hline$\alpha=+20$ & 0.9722 & -0.92 & 17.9541 & -3.8 \\
\hline$\alpha=-10$ & 0.9646 & -2.00 & 17.0646 & -8.0 \\
\hline$\alpha=-20$ & 0.9496 & -3.49 & 15.7753 & -15.0 \\
\hline
\end{tabular}
$315^{\circ}-45^{\circ}$ )

(c) Asymmetrical glaze-Bottom $\left(\theta=135^{\circ}-225^{\circ}\right)$

\begin{tabular}{lllll}
\hline $\begin{array}{l}\text { Angle of at- } \\
\text { tack, deg. }\end{array}$ & $\begin{array}{l}\text { Total pressure } \\
\text { recovery, } \sim\end{array}$ & Decrease, $\%$ & $\begin{array}{l}\text { Mass flow rate, } \\
\mathrm{kg} / \mathrm{s}\end{array}$ & Decrease, $\%$ \\
\hline$\alpha=0$ & 0.9668 & -1.11 & 17.2674 & -4.2 \\
\hline$\alpha=+10$ & 0.9569 & -2.48 & 16.5858 & -10.6 \\
\hline$\alpha=+20$ & 0.9445 & -3.74 & 15.5858 & -16.5 \\
\hline$\alpha=-10$ & 0.9772 & -0.72 & 18.0819 & -2.6 \\
\hline$\alpha=-20$ & 0.9778 & -0.62 & 18.1715 & -2.1 \\
\hline
\end{tabular}

(d) Asymmetrical

\begin{tabular}{lllll}
\hline $\begin{array}{l}\text { Sideslip angle, } \\
\text { deg. }\end{array}$ & $\begin{array}{l}\text { Total pressure } \\
\text { recovery, } \sim\end{array}$ & Decrease, $\%$ & $\begin{array}{l}\text { Mass flow rate, } \\
\mathrm{kg} / \mathrm{s}\end{array}$ & Decrease, $\%$ \\
\hline$\beta=0$ & 0.9729 & -0.49 & 17.7594 & -1.5 \\
\hline$\beta=+10$ & 0.9763 & -0.74 & 18.1675 & -2.8 \\
\hline$\beta=+20$ & 0.9773 & -0.59 & 18.3526 & -2.1 \\
\hline$\beta=-10$ & 0.9635 & -2.04 & 17.0713 & -8.7 \\
\hline$\beta=-20$ & 0.9466 & -3.71 & 15.7569 & -16.0 \\
\hline
\end{tabular}

glaze-Side $(\theta=$ $\left.45^{\circ}-135^{\circ}\right)$

Table 3. Total pressure recoveries $\left(\overline{\mathrm{p}}_{\text {tef }} / \mathrm{p}_{t \infty}\right)$ and inlet mass flow rates with comparison to clean case at angles of attack and sideslip angles $\left(\mathrm{p}_{t \infty}=101.1 \mathrm{kPa}, \mathrm{M}_{\infty}=0.34\right)$. 

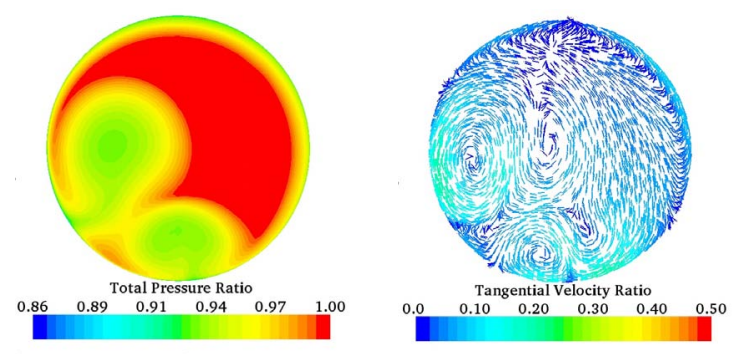

(a) $\alpha=0^{\circ}$
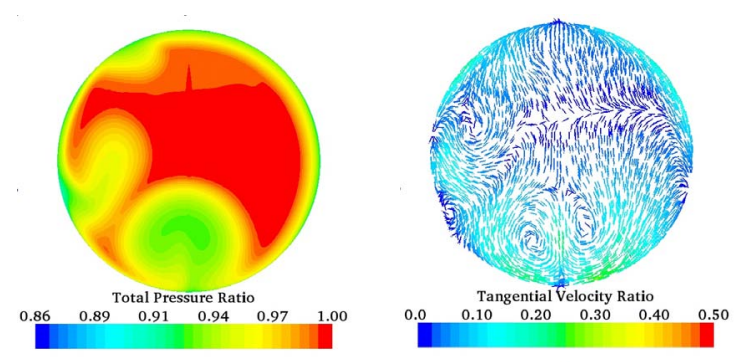

(b) $\alpha=+20^{\circ}$
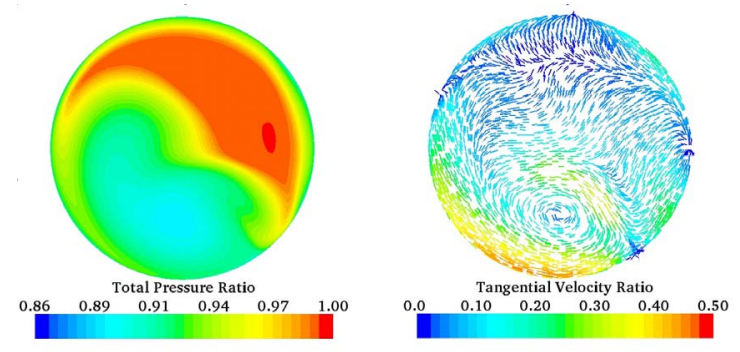

(c) $\alpha=-20^{\circ}$

Figure 18. Total pressure $\left(\mathrm{p}_{t} / \mathrm{p}_{t \infty}\right)$ contours and the secondary flowfields $\left(\mathrm{V} / \mathrm{V}_{\infty}\right)$ at the engine face at sideslip angles (asymmetrical glaze-side, $\mathrm{p}_{t \infty}=101.1 \mathrm{kPa}$, $\left.\mathrm{M}_{\infty}=0.34\right)$.

mance. In addition, there is no considerable difference between the distortion levels caused by $\alpha=+10^{\circ}$ and $+20^{\circ}$ with the top-glaze ice case. However we may conclude that the top-glaze iced inlet duct is adversely affected by angle of attack, as it suffers higher levels of total pressure loss and engine face distortion.

The bottom-glaze ice cases are also summarized in Table 3(c). Contrary to the top-glaze cases, higher levels of loss are induced at the positive angle of attack; and the maximum reduction occurs at $\alpha=+20^{\circ}$. The effect of $\alpha=+20^{\circ}$ was anticipated by the engine face distortion pattern in Figure 17(b). An unanticipated result was that a slight improvement was produced in total pressure recovery (and mass flow rate) with negative angle of attack, as compared to the case of zero inflow angularity. As shown in Table 3(c), $\overline{\mathrm{p}}_{\text {tef }} / \mathrm{p}_{t \infty}=0.9668$ at $\alpha=0^{\circ}$, and $\overline{\mathrm{p}}_{\text {tef }} / \mathrm{p}_{t \infty}=0.9778$ at $\alpha=-20^{\circ}$. This result is also confirmed in Figure 17(c) which shows that the distorted re- gion (caused by flow separation in the S-duct) is reduced at $\alpha=-20^{\circ}$. The rationale for this behavior is that the effect of the bottom-glaze ice is diminished with negative angle of attack, combined with the duct bend effect. The negative angles of attack mitigate the strong flow separation from the downward duct bend, allowing more core flow to reach the engine face. Also, the lip flow separation from the bottom glaze is attenuated with negative angles of attack. Compare to the cases of $\alpha=0^{\circ}$, the total pressure recovery and inlet mass flow are increased by 1.1 and 5.2 percent, respectively, at $\alpha=-20^{\circ}$, whereas at $\alpha=+20^{\circ}$ those are decreased by 2.3 and 9.7 percent, respectively.

The side-glaze ice cases in Table 3(d) indicate that the degraded inlet performance occurs at the negative sideslip angles along with the side glaze, as predicted in Figure 18. Furthermore, the total pressure recovery and inlet mass flow rate decrease more at $\beta=-20^{\circ}$ than at $\beta=-10^{\circ}$. Compared to the $\beta=0^{\circ}$ cases in Table 3(d), the total pressure recovery is reduced by about 2.7 percent, and inlet mass flow is decreased by 11.3 percent at $\beta=-20^{\circ}$. However, the effects of the positive sideslip angles are not critical, as shown in Table 3(d).

Again, the most serious distortion levels occur at $\alpha=$ $-20^{\circ}$ for the top-glaze, at $\alpha=+20^{\circ}$ for the bottom-glaze, and at $\beta=-20^{\circ}$ for the side-glaze ice case, as summarized in Table 4 . Note that the total pressure recovery and mass flow rate of the bottom-glaze case at its worst inflow angle $\left(\alpha=+20^{\circ}\right)$ is slightly lower than those of the other asymmetrical icing cases at their worst inflow angles. However, there is no significant difference between the total pressure recoveries of the asymmetrical cases at their worst inflow angle.

In conclusion, all inlet angles of attack and inlet sideslip angles contributed to the degradation of the inlet performance, combined with the effects of the simulatedsymmetrical-glaze ice shapes. In particular, higher positive angles of attack resulted in more serious steady-state inlet distortion. At $\alpha=0^{\circ}$, the reduction of the mean total pressure recovery by the symmetrical glaze ice was about 6.8 percent from the clean case at the same angle; however, it further decreased to 8.5 percent at $\alpha=+20^{\circ}$, as shown in Table 3(a).

The inlet performance was also sensitive to the inlet angles of attack or sideslip angles with the simulatedasymmetrical ice shapes; top-, bottom-, and side-glaze ice. However, the influence of each ice shape on the inlet performance became more significant at a specific angle, due to the coupled effect of the angles, icing locations, and downward duct bend. The most serious degradation in the inlet performance occurred at $\alpha=-20^{\circ}, \alpha=+20^{\circ}$, and $\beta=-20^{\circ}$ for the top-, bottom-, and side-glaze ice cases, respectively. However, the ice-induced flow blockage was still a critical issue for the inlet performance, since the symmetrical glaze induced substantially lower total pressure re- 


\begin{tabular}{llll}
\hline Case & $\begin{array}{l}\text { Most dis- } \\
\text { tortion an- } \\
\text { gle, } \sim\end{array}$ & $\begin{array}{l}\text { Total pres- } \\
\text { sure recov- } \\
\text { ery, } \sim\end{array}$ & $\begin{array}{l}\text { Mass flow } \\
\text { rate, Kg/s }\end{array}$ \\
\hline Top-glaze & $\alpha=-20$ & 0.9496 & 15.7753 \\
\hline $\begin{array}{l}\text { Bottom- } \\
\text { glaze }\end{array}$ & $\alpha=+20$ & 0.9445 & 15.5858 \\
\hline Side glaze & $\beta=-20$ & 0.9466 & 15.7569 \\
\hline
\end{tabular}

Table 4. Total pressure recoveries $\left(\overline{\mathrm{p}}_{\text {tef }} / \mathrm{p}_{t \infty}\right)$ and inlet mass flow rates for asymmetrical glaze cases at the most distortion angles $\left(\mathrm{p}_{t \infty}=101.1 \mathrm{kPa}, M_{\infty}=0.34\right)$.

coveries, compared to the asymmetrical glaze cases (of $90^{\circ}$ extent), at all angles of attack or sideslip angles.

\section{Conclusions and Recommendation for Future Work}

Flow angularity impacts an S-duct inlet with icing in total pressure recovery; mass flow rate and engine face distortion levels. In general, the inlet performance degradation increases with increasing levels of flow angularity and asymmetry in ice accretion. Although ice accretion is a time-dependent phenomenon, our simulation was based on steady-state flow calculations. The asymmetry in ice accretion was simulated through $90^{\circ}$ sectors of glaze ice on the cowl lip, which showed their sensitivity to inflow angularity. For each case, we established the inflow angle that caused the lowest mean total pressure recovery and reduced mass flow rate and the magnitude of these losses.

The following list constitutes additional areas in icing research that require attention:

- The effects of ice accretion should be extended beyond the S-duct inlet lip. An experimental study showed that ice accretion occurred not only on the external inlet lip, but also along the interior side wall of an inlet duct ([29]).

- A wider range of inlet flow blockage levels must be investigated to find the most critical icing limit on inlet performance.

- Multiphase (gas-liquid) time-dependent flow is required to investigate the effect of ice accretion on an $\mathrm{S}$-duct inlet. It is known that the shape of ice accretion on aircraft's surface changes with time, as well as freestream velocity $\left(\mathrm{V}_{\infty}\right)$, static temperature $\left(\mathrm{T}_{s \infty}\right)$, liquid water content (LWC), etc. ([9]).

- The effect of unsteadiness caused by vortex shedding from the horns of inlet glaze ice should be investigated. This phenomenon gives rise to time-dependent distortion at the engine face, which is called inlet dynamic distortion. The temporal sharp peaks of dynamic distortion, which last on the order of compressor through flow time scale, lead to compressor stall and engine surge.

- The effect of atmospheric gusts or atmospheric turbulence on dynamic inlet distortion should be studied under icing conditions. The disturbances in the freestream, including atmospheric gusts and turbulence, can be another source of the inlet dynamic distortion ([30]).

\section{Acknowledgments}

The authors express their sincere appreciation to Dr. ChuanTau (Eddie) Lan, Emeritus Distinguished Professor of Aerospace Engineering at the University of Kansas, who has continually supported this work.

\section{References}

[1] J. Cole and W. Sand, Statistical Study of Aircraft Icing Accidents, AIAA Paper 91-0558, 1991.

[2] M. G. Potapczuk, Numerical Analysis of an NACA 0012 Airfoil with Leading-Edge Ice Accretion, Journal of Aircraft 25 (1988), no. 3, pp 193-194, Mar. 1988.

[3] M. B. Bragg, A. Khodadoust and S. A. Spring, Measurement in a Leading-Edge Separation Bubble due to a Simulated Airfoil Ice Accretion, AIAA Journal 30 (1992), no. 6, 1462-1467.

[4] M. F. Kerho and M. B. Bragg, Airfoil Boundary-Layer Development and Transition with Large Leading-Edge Roughness, AIAA Journal 35 (1997), no. 1.

[5] H. S. Kim and M. B. Bragg, Effects of Leading-Edge Ice Accretion Geometry on Airfoil Performance, AIAA Paper 993150, 1999.

[6] J. Chung, Y. Choo, A. L. Reehorst, M. G. Potapczuk and J. Slater, Navier-Stokes Analysis of the Flowfield Characteristics of and Ice Contaminated Aircraft Wing, AIAA Paper 99-0375, 1999.

[7] L. W. Acker and K. S. Kleinknecht, Effects of Inlet Icing on Performance of Axial-Flow Turbojet Engine in Natural Icing Conditions, NACA Research Memorandum E50C15, 1950.

[8] T. F. Gelder, Total-Pressure Distortion and Recovery of Supersonic Nose Inlet with Conical Centerbody in Subsonic Icing Conditions, NACA Research Memorandum E57G09, 1957.

[9] C. S. Bidwell and S. R. Mohler Jr., Collection Efficiency and Ice accretion Calculations for a Sphere, a Swept MS(1)-317 Wing, a Swept NACA-0012 Wing Tip, an Axisymmetric Inlet, and a Boeing 737-300, AIAA Paper 95-0755, 1995.

[10] C. S. Bidwell and M. G. Potapczuk, Users Manual for the NASA Lewis Three-Dimensional Ice Accretion Code (LEWICE3D), NASA TM-105974, 1993.

[11] W. Jin and R. R. Taghavi, Computational Study of Icing Effects on the M2129 S-Duct Inlet, AIAA Paper 08-0075, 2008.

[12] J. Seddon and E. L. Goldsmith, Intake Aerodynamics, 2nd edition, AIAA Inc. and Blackwell Science Ltd., Osney, UK, 1999. 
[13] R. W. Guo and J. Seddon, An Investigation of the Swirl in an S-Duct, Aeronautical Quarterly 33 (1982), no. 1, 25-58.

[14] A. C. Willmer, T. W. Brown and E. L. Goldsmith, Effects of Intake Geometry on Circular Pitot Intake Performance at Zero and Low Forward Speeds, Aerodynamics of Power Plant Installation, 5.1-5.16 (AGARD CP301, Paper 5), Toulouse, France, 1981.

[15] J. Gibb and M. Jackson, Some Preliminary Results from Tests Using Vortex Generators in the Circular/Circular Diffusing S-Duct Model M2129 Test Phase 3, Defense Research Agency Rept. AP4(92)WP15, 1992.

[16] M. Papadakis, G. W. Zumwalt, R. Elangonan, G. A. Freund Jr., M. Breer and L. Whitmer, An Experimental Method for Measuring Water Droplet Impingement Efficiency on Twoand Three-Dimensional Bodies, NASA-CR-4257, 1989.

[17] GAMBIT Software Package, Ver. 2.2.30, Fluent Inc., Lebanon, NH, USA, 2004.

[18] STAR-CCM+ Software Package, Ver. 2.10.013, CD-adapco Inc., Melville, NY, USA, 2007.

[19] B. H. Anderson and S. Farokhi, A study of Three Dimensional Turbulent Boundary Layer Separation and Vortex Flow Control Using the Reduced Navier Stokes Equations, Turbulent Shear Flow Symposium, Munich, Germany, 1991.

[20] AGARD Fluid Dynamics Panel Working Group 13, Air Intakes for High Speed Vehicles, AR-270, Fort Worth, TX, USA, 1991.

[21] F. R. Menter, Two-Equation Eddy-viscosity Turbulence Models for Engineering Applications, AIAA Journal 32 (1994), no. 8, 1598-1605.
[22] R. D. D. Menzies, K. J. Babcock, G. N. Barakos and B. E. Richards, Validation of the Simulation of Flow in an S-duct, AIAA Paper 2002-2808, 2002.

[23] N. E. May, A New Vortex Generator Model for Use in Complex Configuration CFD Solvers, AIAA Paper 2001-2434, 2002.

[24] B. L. Berrier and B. G. Allan, Experimental and Computational Evaluation of Flush-Mounted, S-Duct Inlets, AIAA Paper 2004-764, 2004.

[25] S. R. Mohler Jr., WIND-US Flow Calculations for the M2129 S-Duct Using Structured and Unstructured Grids, AIAA Paper 2004-525, 2004.

[26] FLUENT Software Package, Ver. 6.2.16, Fluent Inc., Lebanon, NH, USA, 2005.

[27] J. Dunham, The Generation of Swirl in an S-Duct with Axial Flow, NGTE unpublished memo, 1979.

[28] A. K. Jakubowski and R. W. Luidens, Internal CowlSeparation at High Incidence Angles, AIAA Paper 75-64, 1975.

[29] M. Papadakis, K. E. Hung, G. T. Vu, H. W. Yeong, C. S. Bidwell, M. D. Breer and T. J. Bencic, Experimental Investigation of Water Droplet Impingement on Airfoils, Finite Wings, and an S-Duct Engine Inlet, NASA TM 2002-211700, 2002.

[30] C. J. Macmiller and W. R. Haagenson, Unsteady Inlet Distortion Characteristics with the $\mathrm{B}-1 \mathrm{~B}$, The Propulsion and Energetic 68th (A) Specialists' Meeting, Munich, Germany, 1986. 